\title{
FATTY ACID PROFILE AND EFFECT OF FISH FERMENTED SILAGE ON DIGESTIVE ENZYMES IN Labeo rohita
}

\author{
PERFIL DE ÁCIDOS GRAXOS E EFEITO DE PEIXE FERMENTADO EM SILAGEM \\ DE ENZIMAS DIGESTIVAS EM Labeo rohita
}

\section{Muhammad Sultan HAIDER ${ }^{1}$; Zeeshan $\mathrm{ALI}^{2}$; Sumaira ABBAS ${ }^{3}$; Asif NASEEM ${ }^{4}$; Muhammad AHMAD ${ }^{5}$; Shahid KAMAL ${ }^{6}$; Muhammad AFZAL ${ }^{7}$}

1. Department of Zoology, The University of Lahore, Pakistan. sultan.haidar@imbb.uol.edu.pk; 2. Department of Analytical Chemistry, Pakistan Counsel of Scientific Research, Lahore, Pakistan; 3. Department of Fisheries and Aquaculture, University of Veterinary and Animal Sciences, Lahore, Pakistan; 4. Department of Zoology, Quaid-e-Azam University Islamabad, Pakistan; 5. Department of Zoology, Virtual University, Pakistan; 6. Department of Zoology, Government College Jhang, Pakistan.

\begin{abstract}
Due to inconsistency in demand and supply of fishmeal there is immense need of alternate protein sources. Present project was therefore designed to replace costly fishmeal (FM) with low-priced fermented fish silage (FFS) in fish feed. Fermented fish silage was prepared by fermentation process using Lacto bacillus bacteria and its fatty acid profile and effect on digestive system of Labeo rohita was investigated. Lipid contents were isolated by Soxhlet apparatus and recorded as $6.23 \pm 1.23 \mathrm{~g} / 100 \mathrm{~g}$ of fermented fish silage (FFS). Fatty acid profile of extracted Lipids was determined by gas liquid chromatography (GLC), sufficient amount of unsaturated fatty acids were found with pattern mono unsaturated fatty acids (MUFA) $>$ saturated fatty acids (SFA) > poly unsaturated fatty acids (PUFA). Three treatment diets containing $100 \%$ silage $\left(\mathrm{T}_{1}\right), 75 \%$ silage $\left(\mathrm{T}_{2}\right)$ and $50 \%$ silage $\left(\mathrm{T}_{3}\right)$ were prepared by mixing it with soybean meal (SBM) and rice bran as co-ingredients while fermented fish silage was replaced by fishmeal in control diet $\left(\mathrm{T}_{0}\right)$. The experiment was conducted in glass aquaria in triplicate. Fish growth parameters were recorded fortnightly while physicochemical parameters of water were recorded on daily basis. After completion of feeding trial, three fish were randomly dissected to excise out their intestines and determine activity for protease, amylase and lipase enzymes. Non-significant differences $(\mathrm{P}<0.05)$ were recorded in growth parameters and enzymatic activity among all diets except lipase enzyme. Deceptively, it can be concluded that FFS has reasonable concentration of nutrients and unsaturated fatty acids so it can successfully replace fishmeal in fish diets.
\end{abstract}

KEYWORDS: Feed. Thin layer chromatography. Amylase. Fishmeal. Fatty acids

\section{INTRODUCTION}

After capture, fish is immediately degutted to avoid putrefaction. During degutting and processing of fish, a large amount of waste is produced in the form of scale, skin, fins and body viscera which is buried inland or disposed off in sea, resulting environmental pollution (Nagai; Suzuki, 2000). Effective use of this waste for extraction of some valuable products like collagen, gelatin and enzymes can reduce dispose off cost and generate revenue (TIDWELL; ALLAN, 2001). Another possible alternative method to get rid of this waste material is to convert it into animal feed after proper processing (KROGDAHL et al., 2005).

Protein is a major feed ingredient in aqua feeds and major source of this protein is fishmeal (TONGSIRI et al., 2010). With passage of time demand for fishmeal is increasing and its supply is being restrictive. This difference of demand and supply results in high cost and scarcity of fishmeal, efforts are turning to search alternate of fishmeal (LAPIE; BIGUERAS, 1992; NADEESHA et al., 2011). A successful substituent of fish meal is fish silage which can be prepared by fermentation processing of this waste body viscera (GERON et al., 2007).

Fish silage contains large amount of essential nutrients like protein and fats (CHAKRABARTI; SHARMA, 2005; BOLASINA et al., 2006). Fats of fish silage are usually categorized as saturated, unsaturated, mono unsaturated and poly unsaturated fatty acids. Polyunsaturated fatty acids (PUFA) are important component of fish feed and play a dynamic role in fish growth, and other animals including human beings (NETTLETON, 1991; KLOR et al., 1997; JABEEN; CHAUDHRY, 2011). Therefore, lipid profile analysis is an essential tool to determine and assess nutritional value of any diet. Since fats possess double amount of energy as compared to non-protein energy sources so utilization of fats spare protein for other constructive purposes in fish body (LEE; PUTNAM, 1973). Different researchers have used fish silage successfully in diet of different fish species e.g. Atlantic salmon (Salmo salar) (PARRISH et al., 1991), rainbow trout (Oncorhynchus mykiss) (AKSNES et al., 2006), 
tilapia (Oreochromis niloticus) (FAGBENRO et al., 1994) and for carp larvae (Cyprinus carpio) (CARVALHO et al., 1997). They proved that digestibility of fish silage varies according to raw material used for silage preparation, type of experimental fish and enzymes concentration in fish digestive tract (SEENAPPA; DEVARAJ, 1995; STONE, 2003). These digestive enzymes along other bacteria and micro-organisms help in food digestion so they affect feed digestibility (GARCIACARREN; HAARD 1993; FURNE et al., 2008). Digestion of protein mainly depends upon ingredient composition and enzymes concentration in the digestive tract of fish (ALEXIS, 1990). The information obtained by enzyme study can help to design feed management and feed type (FERNANDEZ et al., 2011). In south Asia, and especially in Indian sub-continent, Labeo rohita, is most preferred fish species and cultured in ponds (MISRA; SAMANTARAY, 2004). Hence, the same fish species was selected as an experimental fish in the current project.

The aim of present research project was to analyze fatty acid profile of fish fermented silage and to check possible effects of silage incorporated diets on digestive enzyme activity in Labeo rohita intestine.

\section{MATERIAL AND METHODS}

Present experiment was performed in at The University of Lahore, Pakistan. Fish body viscera were collected from local fish market. Collected viscera were washed with distilled water twice to remove mud and other un-necessary material. After washing, collected viscera were minced with electric mincer and poured in plastic tubs having lids. Molasses 5\% (as source of sugar), yogurt 5\% (as source of starter culture), orange peels 30\% (as filler) and already minced body viscera $60 \%$ were mixed and thoroughly stirred (FAGBENRO; JAUNCEY 1998). Whole mixture was stored at ambient temperature in an-aerobic conditions. Initially, the mixture was solid but with the passage of time as lactic acid was produced by Lacto bacillus bacteria its $\mathrm{pH}$ started to decrease and mixture started to liquefy. At the end of thirty days storage period, dark brown pasty type material with strong fishy smell was produced. At the top of fermented silage there was liquid lipid layer which was removed manually.

\section{Sample analysis for fatty acid analysis}

For lipid extraction Bligh; Dyer (1959) was followed. Boron rifluoride-methanol complex was used for esterification. The fatty acid methyl esters were used as standards for fatty acid comparisons. Fattori et al (1987) was followed for preparation of methyl esters. Reagent 2, 7-dichlorofluorescein was used for color spots of lipid under ultra violet light; $\lambda 366 \mathrm{~nm}$. Fatty acid analysis was performed by gasliquid chromatography (GLC) at Pakistan Council of Scientific and Industrial Research (PCSIR), Lahore. Fatty acid methyl esters (FAME) were separated identified and quantified using GLC. Helium gas was used as a carrier agent. Methyl esters were identified by their comparison with chromatograms of standards. Peaks were identified by their retention time (KIESSLING et al., 2001).

\section{Diets Preparation}

Already prepared fermented fish silage was oven dried at $80^{\circ} \mathrm{C}$ in an electric oven and grinded in fine powder form by grinding mill. Proximate analysis the silage was performed to check nutritional value of silage (AOAC, 1990). Four isonitrogenous diets were prepared by incorporation of fish silage at different ratios viz. $100 \%, 75 \%$, and $50 \%$ along with other co- ingredients i.e. rice bran and soybean meal. These diets were designated as $\mathrm{T}_{1}, \mathrm{~T}_{2}$, and $\mathrm{T}_{3}$ while fourth control diet was prepared by inclusion of fish meal instead of fish silage and was termed as $\mathrm{T}_{0}$ (Table 1 ).

Table 1. Percentages of various feed ingredients and protein levels used in four treatment diets

\begin{tabular}{lllllllll}
\hline Ingredients & \multicolumn{2}{c}{$\mathbf{T}_{\mathbf{1}}$} & \multicolumn{2}{c}{$\mathbf{T}_{\mathbf{2}}$} & \multicolumn{2}{c}{$\mathbf{T}_{\mathbf{3}}$} & \multicolumn{2}{c}{$\mathbf{T}_{\mathbf{0}}$} \\
\cline { 2 - 10 } & $\begin{array}{l}\text { Weight } \\
(\mathrm{g})\end{array}$ & $\mathrm{CP} \%$ & $\begin{array}{l}\text { Weight } \\
(\mathrm{g})\end{array}$ & $\mathrm{CP} \%$ & $\begin{array}{l}\text { Weight } \\
(\mathrm{g})\end{array}$ & $\mathrm{CP} \%$ & $\begin{array}{l}\text { Weight } \\
(\mathrm{g})\end{array}$ & $\mathbf{C P} \%$ \\
\hline Fish meal & - & & - & & & & 32 & 12.8 \\
Fish silage & 100 & 30.18 & 75 & 21 & 50 & 14.15 & - & \\
Soybean meal & - & & 18 & 8.4 & 30 & 14.13 & 29 & 13.63 \\
Rice bran & - & & 7 & 0.8 & 20 & 2.23 & 39 & 4.9 \\
Total & 100 & 30.18 & 100 & 30.2 & 100 & 30.51 & 100 & 31.33 \\
\hline
\end{tabular}




\section{Feeding Trials}

Labeo rohita fingerlings with an average weight of $13.25 \pm 5.23 \mathrm{~g}$ were obtained from Fish Hatchery Bhagtanwala, district Sargodha, Punjab, and brought to Laboratory at The University of Lahore. Fingerlings were acclimatized in glass aquaria dimensions Length $x$ width $\times$ height $\left(3^{\prime} \times\right.$ $\left.2^{\prime} \times 2^{\prime}\right)$. One third of aquaria were filled with fresh water and oxygen level was enhanced by electric aerator. Fifteen fingerlings were kept in each aquarium in triplicate. Water quality parameters i.e. dissolved oxygen; temperature and $\mathrm{pH}$ were kept within optimum range and recorded on daily basis. Fingerlings were fed twice a day @ 4\% of their body weight. Experiment continued for 92 days. Fish weight and length were recorded before initiation of experiment and thereafter these growth parameters including feed conversion ratio (FCR), and survival rate were calculated fortnightly.

\section{Enzyme activity}

After completion of feeding experiment, three fish from each aquarium were randomly selected, sacrificed and their gut contents were taken out and stored in $10 \%$ formalin solution for further processing and to check their effect on enzyme activity in intestine.

Fish intestines were excised out and washed with cold distilled water. Intestines were homogenized by electrical homogenizer and centrifuged at 20,000 round per minute (RPM) for $10 \mathrm{~min}$ at $0^{\circ} \mathrm{C}$. The supernatant was removed and used as enzyme assays for further proceeding to check proteolysis enzyme activity.

To check proteolysis enzyme activity prepared supernatant was mixed with phosphate buffer $(\mathrm{pH} 7.5)$ and $1 \%$ casein. Mixture was incubated at $35^{\circ} \mathrm{C}$ for $20 \mathrm{~min}$. Thereafter, $5 \%$ TCA was added to stop reaction. Optical density of sample was checked by photometer $\lambda 280 \mathrm{~nm}$. Tyrosine curve was used as standard and activity was expressed as mole of tyrosine released $/ \mathrm{min} / \mathrm{mg}$ protein (KUNITZ, 1947).

For determination of lipase activity, reaction mixture was prepared by mixing phosphate buffer solution ( $\mathrm{pH}$ 7.5), tissue homogenate, distilled water, and olive oil emulsion. After mixing, mixture was incubated at $24^{\circ} \mathrm{C}$ for 24 hour in electric oven. Mixture was titrated with $0.05 \mathrm{~N}$ Sodium hydroxide $(\mathrm{NaOH})$ until appearance of pink color. Amount of Sodium hydroxide $(\mathrm{NaOH})$ required maintaining $\mathrm{pH}$ was used to measure amount of fatty acids released. Enzyme source without emulsion and buffer was used as standard (CHERRY; CRANDALL, 1932).

To determine Amylase activity starch solution, prepared in phosphate buffer $(\mathrm{pH}$ 7.5) was used as substrate. Already prepared reaction mixture consisting of enzyme supernatant, starch solution and distilled water were mixed well and incubated at $35^{\circ} \mathrm{C}$ for $30 \mathrm{~min}$ in electric oven. After 30 minutes, $5 \mathrm{ml}$ of $5 \%$ dinitro salicylic acid (DNS) solution was added in mixture to stop reaction. Mixture was diluted by addition $20 \mathrm{~mL}$ distilled water. Optical density was recorded by photometer at $\lambda 540 \mathrm{~nm}$. Standard maltose curve was used for comparison of amylase activity (RICK; STEGBAUR 1974).

\section{Statistical analysis}

Statistical analysis software (SAS) version 9.1 was used to analyze data. Analysis of variance (ANOVA) with significance level $(\mathrm{p}<0.05)$ was applied to check variations in mean values. The results are presented as means with standard deviation.

\section{RESULTS AND DISCUSSIONS}

Anti-nutritional factors present in raw material and palatability of mixtures must be considered (AZEVEDO, 1998) while formulating fish feeds. Other factors viz. price, availability of ingredients used as raw also play significant role in selection of ingredients to prepare fish diets. Soybean meal along with other ingredients such as rice bran, corn flour and milk powder can be successfully used for fish feed formulations (VIDOTTI et al., 2002; SHABBIR et al., 2003). All the factors were considered in preparation of fish feed during current study. Results of proximate analysis of treatment diets are presented in Table 2 .

Table 2. Nutrient composition of various prepared treatment diets

\begin{tabular}{lllll}
\hline Parameters & $\mathbf{T}_{1}$ & $\mathbf{T}_{2}$ & $\mathbf{T}_{3}$ & $\mathbf{T}_{\mathbf{0}}$ \\
\hline Protein $(\%)$ & $29.98 \pm 0.11^{\mathrm{a}}$ & $30.14 \pm 0.07^{\mathrm{a}}$ & $30.28 \pm 0.41^{\mathrm{a}}$ & $32.14 \pm 0.18^{\mathrm{a}}$ \\
Fats $(\%)$ & $12.58 \pm 0.14^{\mathrm{a}}$ & $11.81 \pm 0.41^{\mathrm{a}}$ & $12.17 \pm 1.38^{\mathrm{a}}$ & $9.41 \pm 0.71^{\mathrm{b}}$ \\
Ash $(\%)$ & $8.69 \pm 0.49^{\mathrm{a}}$ & $9.89 \pm 1.32^{\mathrm{a}}$ & $9.31 \pm 0.48^{\mathrm{a}}$ & $4.88 \pm 0.54^{\mathrm{b}}$ \\
Carbohydrates $(\%)$ & $5.30 \pm 1.82^{\mathrm{b}}$ & $4.81 \pm 0.79^{\mathrm{b}}$ & $7.88 \pm 1.23^{\mathrm{a}}$ & $5.61 \pm 0.76^{\mathrm{b}}$
\end{tabular}

Means with same letters in a single row are statistically similar at $(\mathrm{P}<0.05)$. 
Analysis of results showed that all treatment diets contained reasonable amount of lipid contents. The lipid contents were calculated as $12.58 \pm 0.14 \%$, $11.81 \pm 0.41 \%, 12.17 \pm 1.38 \%$ and $9.41 \pm 0.71 \%$ in $\mathrm{T}_{1}, \mathrm{~T}_{2}, \mathrm{~T}_{3}$ and $\mathrm{T}_{0}$ diets, respectively. Amount of lipids in prepared silage varied according to type of raw material, life stage of fish and nature of diet to be fed to the fish (DEWAILLY et al., 2001; KHODDAMI et al., 2009). High concentration of lipid contents in the silage prepared during present project can be defended by NELSON AND COX (2000) who reported that quantity of fat contents in silage varies according to the type of raw material used for silage preparation. Final composition and nutritive value of silage varies significantly according to the type of raw material, season of fish harvesting and even varies in the same type of fish (KOMPIANG, 1981; ARRUDA, 2004).

\section{Fatty acid analysis}

Amount of extracted lipid contents were recorded as $6.23 \pm 1.23 \mathrm{~g} / 100 \mathrm{~g}$ of sample in prepared silage. Fatty Acid profile recorded after analysis is presented in Table 3.

Table 3. Fatty Acid analysis of pure fermented fish silage

\section{Sr. No. $\quad$ Fatty Acid*}

Fermented Fish silage

\begin{tabular}{|c|c|c|c|c|c|}
\hline & & I & II & III & Average \\
\hline 1 & $\mathrm{C}_{12: 0}$ & 1.09 & 1.08 & 1.11 & $1.09 \pm 0.01$ \\
\hline 2 & $\mathrm{C}_{14: 0}$ & 13.43 & 14.26 & 15.21 & $14.3 \pm 0.89$ \\
\hline 3 & $\mathrm{C}_{16: 0}$ & 21.28 & 23.11 & 22.76 & $22.38 \pm 0.97$ \\
\hline 4 & $\mathrm{C}_{16: 1}$ & 12.32 & 12.46 & 13.12 & $12.63 \pm 0.42$ \\
\hline 5 & $\mathrm{C}_{18: 0}$ & 5.26 & 5.78 & 6.17 & $5.73 \pm 0.45$ \\
\hline 6 & $\mathrm{C}_{18: 1}$ & 28.21 & 27.32 & 26.13 & $27.22 \pm 1.04$ \\
\hline 7 & $\mathrm{C}_{18: 2}$ & 15.23 & 16.23 & 15.19 & $15.55 \pm 0.58$ \\
\hline 8 & $\mathrm{C}_{18: 3}$ & 1.86 & 1.96 & 1.42 & $1.74 \pm 0.28$ \\
\hline 9 & $\mathrm{C}_{20: 0}$ & 0.66 & 0.72 & 0.83 & $0.73 \pm 0.08$ \\
\hline 10 & $\mathrm{C}_{20: 1}$ & 0.83 & 0.94 & 0.83 & $0.86 \pm 0.06$ \\
\hline 11 & TSFA & 41.72 & 44.95 & 45.97 & $44.21 \pm 2.21$ \\
\hline 12 & MUFA & 40.53 & 39.78 & 40.08 & $40.13 \pm 0.37$ \\
\hline 13 & PUFA & 17.09 & 18.19 & 16.61 & $17.29 \pm 0.81$ \\
\hline 14 & TFA & ND & ND & ND & ND \\
\hline
\end{tabular}

FA $\rightarrow$ Fatty acid, TSFA $\rightarrow$ Total saturated fatty acids, PUFA $\rightarrow$ Poly unsaturated fatty acids, MUFA $\rightarrow$ Mono unsaturated fatty acids.

Results revealed that saturated fatty acids (SFA), mono un-saturated fatty acids (MUFA), and poly unsaturated fatty acids (PUFA) were present in adequate amount in the silage prepared during present investigation and there amount was calculated as $44.21 \pm 2.21 \%, 40.13 \pm 0.37 \%$ and $17.29 \pm 0.81 \%$, respectively. The results indicated that fatty acids are present in relative pattern of SFA $>$ MUFA > PUFA in pure fermented fish silage.

Our results of Fatty Acid profile are similar to the results as described by Disney et al. (1977) and Sales (1995). They analyzed Acid Silage and Fermented Fish Silage and reported 14.84, 12.20 and $14.29 \mathrm{~g} / 100 \mathrm{~g}$ Lipid contents, respectively, in different Fish Silage samples. Similar value was also reported by Dapekevicius et al. (1998) who studied Acid and Fermented Fish Silages, and obtained values of 14.90 and $10.30 \mathrm{~g} / 100 \mathrm{~g}$ respectively. These results are close to our findings. Our results about Fatty Acid profile showed similar pattern of Fatty Acid analysis e.g. SFA > MUFA > PUFA in the profile of Carp fish species from Indus River (JABEEN; CHAUDHRY, 2011). Differences in the pattern of fatty acids profile of fish carcass is influenced by ratio and types of Fats in the fish diet (TOCHER, 2003). Amount of Fatty Acids, especially Unsaturated Fatty Acids, strongly vary in the Wild and Farmed fish species because of variations in their diets (OZOGUL, 2007; KALYXCONCU et al., 2010). Eicosapentaenoic Acid (EPA 20:5n-3) Docosahexaenoic Acid (DHA 22:6n-3) and, probably, Arachidonic Acid (AA, 20:4n-6) are considered essential in the diets for normal growth, and survival of marine and fresh water aquatic organisms (SARGENT et al., 1999).

\section{Feeding Trial:}

Data recoded about fish growth parameters has been presented in Table 4 . 
Table 4. Weight gain, Length gain, FCR, SGR and Survival rate of Labeo rohita fingerlings fed on different treatment diets

\begin{tabular}{lllccc}
\hline Treatments & Total weight gain & $\begin{array}{c}\text { Total length } \\
\text { gain }\end{array}$ & $\begin{array}{c}\text { Feed } \\
\text { conversion } \\
\text { ratio }\end{array}$ & $\begin{array}{c}\text { Specific growth } \\
\text { rate }\end{array}$ & Survival \% \\
\hline $\mathbf{T}_{\mathbf{1}}$ & $7.71 \pm 0.56 \mathrm{a}$ & $8.61 \pm 0.22 \mathrm{a}$ & $2.44 \pm 1.45 \mathrm{~b}$ & $0.87 \pm 0.08 \mathrm{a}$ & $100 \mathrm{a}$ \\
$\mathbf{T}_{\mathbf{2}}$ & $7.27 \pm 0.47 \mathrm{a}$ & $8.51 \pm 0.36 \mathrm{a}$ & $3.35 \pm 0.67 \mathrm{a}$ & $0.89 \pm 0.56 \mathrm{a}$ & $100 \mathrm{a}$ \\
$\mathbf{T}_{\mathbf{3}}$ & $6.59 \pm 0.73 \mathrm{a}$ & $7.89 \pm 0.36 \mathrm{ab}$ & $3.79 \pm 1.58 \mathrm{a}$ & $0.91 \pm 0.16 \mathrm{a}$ & $100 \mathrm{a}$ \\
$\mathbf{T}_{\mathbf{0}}$ & $6.62 \pm 0.48 \mathrm{a}$ & $7.71 \pm 0.56 \mathrm{ab}$ & $2.59 \pm 0.98 \mathrm{~b}$ & $0.90 \pm 0.11 \mathrm{a}$ & $100 \mathrm{a}$ \\
\hline \multicolumn{5}{l}{ Values are presented as Mean with Standard Deviation. The values with same alphabets shows non- significant variation $(\mathrm{P}<0.05)$} \\
\hline
\end{tabular}

According to results, Total weight gain was recorded as $7.71 \pm 0.56,7.27 \pm 0.47,6.59 \pm 0.73$ and $6.62 \pm 0.48$ for $\mathrm{T}_{1}, \mathrm{~T}_{2}, \mathrm{~T}_{3}$ and $\mathrm{T}_{0}$, respectively. Statistical analysis showed non-significant difference $(\mathrm{P}<0.05)$ among treatments. According to Vincent et al. (2002) nutritional quality and digestibility of feed can be best evaluated by feeding trial. Weight gain, Length gain, FCR, SGR and Survival rate are useful parameters to evaluate feed digestibility and quality (VINCENT et al., 2002). Growth rate is mostly affected by protein concentration (KUMAR et al., 2010) and our all treatment diets were iso nitrogenous so there is nonsignificant difference in weight gain among all treatment groups. Protein level has severe effect on fish growth. They reported that protein is major nutrient and its concentration significantly affect fish growth rate (TARINDHA et al., 2003; SINGH et al., 2006). FCR was recorded as $2.44 \pm 1.45$,
$3.35 \pm 0.67,3.79 \pm 1.58$ and $2.59 \pm 0.98$ for $T_{1}, T_{2}, T_{3}$ and $\mathrm{T}_{4}$, respectively. Statistical analysis showed non-significant difference among $T_{2}$ and $T_{3}$ while these two groups showed significant difference from other two groups $T_{1}$ and $T_{0}$. Some other nutrients despite Protein affect digestibility and quality of feed which change FCR value (CHAUDHARY AND QAZI ,2007; MUSTAFA et al., 1994) also reported same results while working on effect of nutrition on growth rate of sea bream.

\section{Enzyme activity}

Enzyme activity of Protease, Amylase and Lipase is presented in Table 5. Protease activity was recoded as $15.63 \pm 0.56,15.32 \pm 1.01,14.02 \pm 0.26$ and $14.06 \pm 0.26$ in $T_{1}, T_{2}, T_{3}$ and $T_{0}$, respectively. The results indicated non-significant variation $(\mathrm{P}<0.05)$ among different treatments.

Table 5. Enzyme activity of Protease, Amylase and Lipase in digestive tract of Labeo rohita fingerlings fed on different treatment diets.

\begin{tabular}{|c|c|c|c|c|}
\hline \multirow[t]{2}{*}{ Enzymes } & \multicolumn{3}{|c|}{ Fermented Fish Silage } & \multirow{2}{*}{$\begin{array}{c}\text { Control } \\
\text { Fermented }\end{array}$} \\
\hline & $100 \%$ & $75 \%$ & $50 \%$ & \\
\hline Protease & $15.63 \pm 0.56 \mathrm{a}$ & $15.32 \pm 1.01 \mathrm{ab}$ & $14.02 \pm 0.26 \mathrm{ac}$ & $14.06 \pm 0.26 \mathrm{ab}$ \\
\hline Amylase & $11.55 \pm 0.98 \mathrm{a}$ & $11.72 \pm 0.91 \mathrm{a}$ & $12.23 \pm 0.55 b$ & $10.09 \pm 0.38 b$ \\
\hline Lipase & $1.29 \pm 0.40 \mathrm{a}$ & $0.93 \pm 0.42 b$ & $0.77 \pm 0.11 \mathrm{c}$ & $1.17 \pm 0.36 \mathrm{a}$ \\
\hline
\end{tabular}

Means with same letters in a single row are statistically similar at $(P<0.05)$.

Enzyme activities are expressed as: Protease as Micromol of Tyrosine released/min/g protein; Amylase as Micromol of Maltose released/min/g protein; Lipase as units/mg protein.

Different researchers have shown different results in this regards. Lopez-Lopez et al. (2005) reported that there is no strong Correlation between Protease activity and dietary crude Protein level. With the increase of Carbohydrate and Protein quantity in the fish diet, activity of Amylase and Protease also increases (LE MOULLAC et al., 1994). However, if the concentration of these components increases beyond limits, concentration of Amylase and Protease start to decrease (CECCALDI, 1997). So our results can be explained on this ground that as our all treatment diets were iso-nitrogenous and Protease activity is mainly dependent upon Protein concentration so there is non-significant $(\mathrm{P}<0.05)$ variation among results.

Amylase activity was recorded as $11.55 \pm 0.98, \quad 11.72 \pm 0.91, \quad 12.23 \pm 0.55$ and $10.09 \pm 0.38$ in $\mathrm{T}_{1}, \mathrm{~T}_{2}, \mathrm{~T}_{3}$ and $\mathrm{T}_{0}$, respectively. Statistical analysis revealed Non-Significant differences between Amylase activities among all treatment diets. These results can be justified by the 
findings of Sabapathi and Teo (1993) and Hidalgo et al. (1999) who recorded lower amylase activity in Carnivorous fish and higher in Omnivorous fish. Our results about amylase activity are in line with who reported no correlation among amylase and dietary carbohydrates contents in diet in Homarus americanus and Cheraxquadr icarinatus, respectively (HOYLE, 1973; LOPEZ-LOPEZ et al., 2005).

Lipase activity was recorded in Fermented Fish Silage as $1.29 \pm 0.40,0.93 \pm 0.42,0.77 \pm 0.11$ and $1.17 \pm 0.36$ in $\mathrm{T}_{1}, \mathrm{~T}_{2}, \mathrm{~T}_{3}$ and $\mathrm{T}_{0}$ respectively. Statistical analysis of Lipase activity showed significant difference $(\mathrm{p}<0.05)$ among all treatments. $\mathrm{T}_{1}$ treatment showed greater Lipase enzyme activity as compared to other treatments. Different researcher revealed different reasons behind Lipase activity variation. It is proved that that fish feeding habits and type of carbohydrate has strong effect Lipase activity (NRC, 1993; SABAPATHI; TEO, 1993). Temperature of environment and season of fish harvesting can influence the digestive enzyme activity in fish (KUZMINA et al., 1996). So our results may vary to some extent from the previous ones.

This difference may also be due to the variation in Lipid concentration in the treatment
HAIDER, M. S. et al

diets. Lipase activity varies according to the amount of Lipid contents in diets and this activity is more prominent in the Carnivorous fishes as compared to other fish species (CHAKRABARTI et al., 1995; LUNDSTEDT et al., 2004).

\section{CONCLUSIONS}

Fermented fish silage contains high concentrations of mono-unsaturated fatty acids which has positive impact upon Labeo rohita growth.

The activity of protease, amylase and lipase do not vary significantly $(\mathrm{P}<0.05)$ if protein, carbohydrate and lipid concentrations are kept constant in the diet.

\section{ACKNOWLEDGEMENTS}

Authors are grateful to Higher Education Commission of Pakistan (HEC) for provision of financial grant and especially thankful to Pakistan Council of Scientific and Industrial Research (PCSIR), Lahore for the provision of technical support for completion of this project.

RESUMO: Devido à diferença na procura e na oferta de farinha de peixe há imensa necessidade de qualquer membro suplente da fonte de proteína. Tão presente projeto foi projetada para substituir a dispendiosa farinha de peixe (FM) com barato peixe fermentado de ensilagem (FFS) em alimentos para peixes. FFS foi preparado pelo processo de fermentação usando Lactobacillus bactérias e seu perfil de ácidos graxos e efeito sobre o sistema digestivo de Labeo rohita foi investigado. Conteúdo lipídico foram isoladas pelo aparelho de Soxhlet e registadas como 6,23 $\pm 1,23 \mathrm{~g} / 100 \mathrm{~g}$ de FFS. Perfil de ácidos graxos extraídos de lipídios foi determinada por cromatografia líquida de gás (GLC). Quantidade suficiente de ácidos graxos insaturados foram encontrados com padrão MUFA > SFA > AGPI. Tratamento de três dietas contendo silagem de $100 \%$ (T1), $75 \%$ silagem (T2) e 50\% silagem (T3) foram preparados misturando com farinha de soja (SBM) e farelo de arroz como co ingredientes enquanto FFS foi substituído pela FM na dieta controle (T0). O experimento foi conduzido em aquários de vidro em triplicado. O Crescimento dos peixes foram anotados os parâmetros quinzenal enquanto parâmetros físico-químicos de água foram registradas diariamente. Após a conclusão do teste de alimentação, três peixes foram aleatoriamente dissecada a impostos especiais de consumo os seus intestinos e determinar a atividade de protease, enzimas amilase e lipase. As variações não significativas $(\mathrm{P}<0,05)$ foi registrada em parâmetros de crescimento e atividade enzimática entre as dietas exceto enzima lipase mostrou diferença significativa entre as dietas de tratamento. Aparentemente, é possível concluir que a concentração razoável de FFS tem nutrientes e ácidos graxos insaturados de modo que ela possa substituir com êxito a farinha de peixe na dieta de peixes.

PALAVRAS-CHAVE: Alimentação. TLC. Amilase. Farinha de peixe. Ácidos gordos

\section{REFERENCES}

ALEXIS, M. N. Comparative evaluation of soybean meal and carob seed germ meal as dietary ingredients for rainbow trout fingerlings. Aquatic Living Resources, v. 3, P. 235-241, 1990.

https://doi.org/10.1051/alr:1990024 
ARRUDA, S. F.; SIQUEIRA, E. M.; SOUZA, T. J. Malanga (Xanthosomasagitti folium) and purslane (Portulacaoleracea) leaves reduce oxidative stress in vitamin A-deficient rats. Annual Nutritional Metabolism, v, 48, p, 288-295, 2004.

BLIGH E.G.; DYER, W. J. Method of total lipid extraction and purification. Canadian Journal of Biochemistry, v. 37, p. 911-917, 1959. +https://doi.org/10.1139/o59-099 https://doi.org/10.1139/y59-099

BOLASINA, S.; PEREZ, A.; YAMASHITA, Y. Digestive enzymes activity during ontogenetic development and effect of starvation in Japanese flounder (Paralichthyso livaceus). Aquaculture, v. 252, p. 503-515, 2006. https://doi.org/10.1016/j.aquaculture.2005.07.015

CHAKRABARTI, I.; GANI, M. D. A.; CHAKI, K. K; SUR, R.; MISRA, K. K. Digestive enzymes in 11 freshwater teleost fish species in relation to food habit and niche segregation. Comparative Biochemistry and Physiology, v. 112, p. 167-177, 1995. https://doi.org/10.1016/0300-9629(95)00072-F

MUSTAFA M, G.; UMINO, T.; MIYAKE, H.; NAKAGAWA, H. Effect of Spirulina sp. Meal as feed additive on lipid accumulation in Red Sea Bream, Pagrus major. Journal of Applied Ichthyology, v. 10, p. 141- 145, 1994. https://doi.org/10.1111/j.1439-0426.1994.tb00153.x

CHAKRABARTI, R.; SHARMA, J. G. Digestive physiology of fish larvae during ontogenic development: a brief overview. Indian Journal of Animal Sciences, v. 75, p. 1337-1347. 2005.

CHERRY, I. S.; CRANDALL, D. The specificity of pancreatic lipase. its appearance in the blood after pancreatic injury. American Journal of Physiology, 100, p. 266-274. 1932.

DISNEY, J. G.; TATTERSON, I. N; OLLEY, J. Recent developments in fish silage. In: Conference on the Handling, Processing and Marketing of Tropical Fish, 1976. Proceedings. London. Ministry of Oversea Development, p. 321- 340, 1977.

DEWAILLY E. E., BLANCHET C., GINGRAS S., LEMIEUX L. AND SAUVE L. Relations between n-3 fatty acid status and cardiovascular disease risk factors among Quebecers. American Journal of Clinical Nutrition, v. 74, p. 603-611, 2001.

FAGBENRO O., JAUNCEY, K., HAYLOR, G. Nutritive value of diets containing dried lactic acid fermented fish silage and soybean meal for juvenile Oreochromis niloticus and Clarias gariepinus. Aquatic Living Resources, v. 7, p. 79-85. 1994. https://doi.org/10.1051/alr:1994010

FAGBENRO, O.; JAUNCEY, K. Physical and nutritional properties of moist fermented fish silage pellets as a protein supplement for Tilapia (Oreochromis niloticus). Animal Feed Science and Technology, v. 71, p. 11 18. 1998. https://doi.org/10.1016/S0377-8401(97)00123-5

FATTORI, M.; BULLEY, N. R.; MEISEN, A. Fatty acid and Phosphorus content of Canola seed extracts obtained with supercritical Carbon dioxide. Journal of Agricultural and Food Chemistry, v. 35, p. 739-743, 1987. https://doi.org/10.1021/jf00077a023

FERNANDEZ, I.; MOYANO, F. J.; DIAZ, M; MARTINEZ, T. Characterization of amylase activity in five species of Mediterranean Sparid Fishes (Sparidae, Teleostei). Jornal of Experimantal Marine Biology Ecology, v. 262, p. 1-12. 2011. https://doi.org/10.1016/S0022-0981(01)00228-3

FURNE, M.; GARCIA-GALLEG, M.; HIDALGO, M. C.; MORALES, A. E.; DOMEZAIN, A.; DOMEZAIN, J; SANZ, A. Effect of starvation and refeeding on digestive enzyme activities in Sturgeon (Acipensernac carii) and Trout (Oncorhynchus mykiss). Comparative Biochemistry and Physiology, v. 149, n. 4, p. 420-425. 2008. https://doi.org/10.1016/j.cbpa.2008.02.002 
VINCENT, S.; AMBROSE, T; SELVANAYAGA, M . Impact of Cadmium on food utilization of the Indian major carp (Catla catla). Journal of Environmental Biology, 23, p. 209-212. 2002.

GERON, L. J. V.; ZEOULA, L. M.; VIDOTTI, R. M.; MATSUSHITA, M.; KAZAMA, R.; NETO, S. F. C; FERELI, F. Chemical characterization, dry matter and crude protein ruminal degradability and in vitro intestinal digestion of acid and fermented silage from tilapia filleting residue. Animal Feed Science and Technology, v. 136, p. 226 - 239. 2007. https://doi.org/10.1016/j.anifeedsci.2006.09.006

HIDALGO, M. C.; UREA, E; SANZ, A. Comparative study of digestive enzymes in fish with different nutritional habits Proteolytic and amylase activities. Aquaculture, v. 170, p. 267-283. 199.

JABEEN, F.; CHAUDHRY, A. Chemical compositions and fatty acid profile of three fresh water fish species. Food Chemistry, v. 125, p. 991-996. 2011. https://doi.org/10.1016/j.foodchem.2010.09.103

KHODDAMI, A.; ARIFFIN, J.; BAKAR, T.; GHAZALI, H. M. Fatty Acid Profile of the Oil Extracted from Fish Waste (Head, Intestine and Liver) (Sardinella lemuru). World Applied Sciences Journal, v. 7 n. 1, p. 127-131, 2009.

KIESSLING, A.; PICKOVA, J.; JOHANSSON, L.; ASGARD, T.; STOREBAKKEN, T.; KIESSLING, K. H. Changes in fatty acid composition in muscle and adipose tissue of farmed Rainbow Trout (Oncorhynchus mykiss) in relation to ration and age. Food Chemistry, v. 73, p. 271-284, 2001. https://doi.org/10.1016/S03088146(00)00297-1

KOMPIANG, I. P. Fish silage: its prospect and future in Indonesia. Indonesia Agriculture Research and Development Journal, v. 3, p. 9-12, 1981.

KROGDAHL, A.; HEMRE, G. I.; MOMMSEN, T. P. Carbohydrates in fish nutrition: digestion and absorption in post larval stages. Aquaculture Nutrition, v. 11, n. 2, p. 103-122, 2005. https://doi.org/10.1111/j.13652095.2004.00327.x

KUMAR, A.; BHATNAGAR, S. K.; GARG, J.; JANA, S. N. Growth performance of Nile tilapia, Oreochromis niloticus (Linn.) in relation to provision of substrate and supplementary feeding, and grown in brackish water ponds. Asian Fish Science, v. 22, n. 4, p. 1211-1233, 2010.

KUNITZ, M. Isolation of a crystalline protein compound of trypsin and of soybean trypsin-inhibitor. Journal of General Physiology, v. 30, p. 311-320. 1947. https://doi.org/10.1085/jgp.30.4.311

https://doi.org/10.1085/jgp.30.4.291

LAPIE, L. P.; BIGUERAS-BENITEZ, C. M. Feeding studies on tilapia Oreochromis sp. using fish silage. In: Ž. James, D. Ed. Proceedings of the IPFC Workshop on Fish Silage. FAO Fisheries Report no. 470, FAO, Rome, p. 165-177. 1992.

LEE, D. J.; PUTNAM, G. B. The response of rainbow trout to varying protein/energy ratios in a test diet. Journal of Nutrition, v. 103, p. 916-912. 1973.

LOPEZ-LOPEZ, S.; NOLASCO, H.; VILLARREAL-COLMENARES, H; CIVERA-CERECEDO, R. Digestive enzyme response to supplemental ingredients in practical diets for juvenile freshwater crayfish Cheraxquadri carinatus. Aquaculture Nutrition, v. 11, p. 79-85, 2005. https://doi.org/10.1111/j.13652095.2004.00305.x

LUNDSTEDT, L. M.; BIBIANOMELO, J. F.; MORAES, G. Digestive enzymes and metabolic profile of Pseudoplatystoma corruscans (Teleostei: Siluriformes) in response to diet composition. Comparative

Biochemistry and Physiology, v. 137, p. 331-339, 2004. https://doi.org/10.1016/j.cbpc.2003.12.003 
MISRA, K.; SAMANTARAY, K. Interacting effects of dietary lipid level and temperature on growth, body composition and fatty acid profile of rohu (Labeo rohita). Aquaculture Nutrition, v. 10, p. 359-369, 2004. https://doi.org/10.1111/j.1365-2095.2004.00311.x

NAGAI, T.; SUZUKI N. Isolation of collagen from fish waste material - skin, bone and fins. Food Chemistry, v. 68, p. 277-281, 2000. https://doi.org/10.1016/S0308-8146(99)00188-0

NELSON, D. L; COX, N. M. Lehninger. Principles of Biochemistry, $3^{\text {rd }}$ Edition. 41 Madison Avenue, New York. Worh Publishers, NY 10010. 2000.

NETTLETON, J. A. n-3 Fatty acids: comparison of plant and seafood sources in human nutrition. J. N Am. Dvets. Assoc., v. 91, p. 331-337, 1991.

NRC. Nutrient Requirements of Fish. National Academy Press, Washington, p. 114. 1993.

OZOGUL, Y.; OZOGUL, F. (2007). Fatty acid profiles and fat content of commercially important seawater and freshwater fish species of Turkey: A comparative study. Food Chemistry, v. 100, p. 1634-1638, 2007. https://doi.org/10.1016/j.foodchem.2005.11.047

PARRISH, C. C.; LI, H.; INDRASENA, W. M.; ACKMAN, R. G. Silage feeds in Atlantic salmon farming: flavour volatiles and lipid composition, feeding trials, and taste panels. Bulleton Aquaculture Association Canada, v. 91, n. 1, p. 75-84. 1991.

RICK, W.; STEGBAUER, H. P. $\alpha$ - amylase of reducing groups. In. H.V. Bergmeyer (ed), Methods of Enzymatic Analysis, v. 2 Aca - demic press, New York. p. 885 - 890, 1974.

SINGH, P. K.; GAUR, S. R.; CHARI, M. S. Growth performance of Labeo rohita (Ham.) fed on diet containing different levels of slaughter house waste. J. Fish. Aquat. Sci., v. 1, p. 10-16. 2006. https://doi.org/10.3923/jfas.2006.10.16

SABAPATHI, U.; TEO, L. H. A quantitative study of some digestive enzymes in rabbit fish, Siganuscanali culatus and the Sea Bass, Latescal carifer. Journal of Fish Biology, v. 42, p. 595-602, 1993. https://doi.org/10.1111/j.1095-8649.1993.tb00362.x

SARGENT, J. R.; MCEVOY, L.; ESTEVEZ, A.; BELL, J. G.; BELL, M. V.; HENDERSON, J. R.; TOCHER, D.R. Lipid nutrition of marine fish during early development: current status and future directions.

Aquaculture, v. 179, p. 217-229, 1999. https://doi.org/10.1016/S0044-8486(99)00191-X

SEENAPPA, D.; DEVARAJ, K. V. Effect of different levels of protein, fat and carbohydrate on growth, feed utilization and body carcass composition of fingerlings in Catla catla. Aquaculture, v. 129, p. 243-249, 1995. https://doi.org/10.1016/0044-8486(94)00273-Q

SHABBIR, S.; SALIM, M.; RASHID, M. Study on the feed conversion ratio (FCR) in major carp Cirrhinus mrigala fed on sunflower meal, wheat bran and maize gluten 30\%. Pakistan Veterinary Journal, v. 23, p. 13, 2003.

STONE, D. A. J. Dietary carbohydrate utilization by fish. Reviews in Fisheries Science, v. 11, p. 337-369, 2003. https://doi.org/10.1080/10641260390260884

TIDWELL, J. H.; ALLAN, G. L. Fish as food: aquaculture's contribution. EMBO, v. 2, n. 11, p. 958-963. 2001. https://doi.org/10.1093/embo-reports/kve236

TOCHER, D. Metabolism and functions of lipid and fatty acid in teleost fish. Reviews in Fisheries Sciences, v. 11, p. 107-184, 2003. https://doi.org/10.1080/713610925 
TONGSIRI, K.; MANG-AMPHAN, T.; YUWADEE, Y. Effect of Replacing Fish meal with Siirulinaon Growth, Carcass Composition and pigment of the Mekong Giant Catfish. Asian Journal of Agricultural Sciences, v. 2 n. 3, p. 106-110, 2010.

VIDOTTI, R. M.; CARNEIRO, D. J.; VIEGAS, E. Acid and Fermented Silage characterization and determination of apparent digestibility coefficient of crude protein for Pacu (Piaractusmeso potamicus). Journal of World Aquaculture Society, v. 33, p. 57-62. 2002. https://doi.org/10.1111/j.17497345.2002.tb00478.x 